\title{
E-Government Implementation Process in Rwanda: Exploring Changes in a Socio- technical Perspective
}

\author{
Pierre Bakunzibake \\ College of Science and Technology, School of ICT, University of Rwanda, Kigali, \\ Rwanda \\ Gunnar O. Klein \\ Centre for Empirical Research on Information Systems, Örebro University School \\ of Business, Örebro, Sweden \\ Sirajul M. Islam \\ Centre for Empirical Research on Information Systems, Örebro University School \\ of Business, Örebro, Sweden
}

\section{Abstract}

Background: Failures in e-government projects to deliver expected results are frequent in the context of developing countries. These are partly attributed to the lack of balanced attention to both technical and social aspects in the implementation. However, there has been limited research on these aspects in the least Developed Countries. Objectives: Taking a socio-technical perspective, this study aims at exploring the extent of changes and effects in the implementation of e-government service-oriented initiatives in Rwanda, one of the Least Developed Countries. Methods/Approach: An empirical investigation was conducted, via interviews at 8 agencies during the period from January 2017 to May 2018. This involved two case projects, an Enterprise Content Management System and a One-Stop e-government system. Furthermore, government documents and online material were analyzed. Results: A number of changes in technology, processes and people aspects were faced in both projects. However, those changes are coupled with secondary effects; there is a need for a better fit between technical systems and social systems of organizations implementing e-government; a larger gap was identified in the first case project. Conclusions: Addressing the issues as a socio-technical system would contribute to improved work systems of agencies and better services.

Keywords: e-Government implementation, enterprise content management, 'one-stop' e-government, Rwanda, socio-technical theory

JEL classification: D73, O33

Paper type: Research article

Received: Jan 10, 2019

Accepted: Feb 22, 2019

Citation: Bakunzibake, P., Klein, G.O., Islam, S.M., (2019), "E-Government Implementation Process in Rwanda: Exploring Changes in a Socio-technical Perspective," Business Systems Research, Vol. 10 No. 1, pp. 53-73.

DOI: 10.2478/bsrj-2019-0005 


\section{Introduction}

There is evidence that the implementation of information system projects can fail to deliver the anticipated benefits due to unbalanced attention to social and technical factors (Luna-Reyes et al., 2005). According to Luna-Reyes et al. (2005), organizational and social factors are more attributable to failures than are technical factors. On the other hand, the 'socio-technical' thinking of Bostrom et al. (1977)-in what they called a fit between 'social' sub-systems (comprised of structures and people aspects) and 'technical' sub-systems (comprised of processes and technology aspects)—shows that balanced attention should be given to both technical and social aspects in organizations implementing new technologies for optimal results. Risks of failures or not getting anticipated results are expected to increase when information systems require the crossing of functional and organizational boundaries (Luna-Reyes et al., 2005). This is the case with e-government information systems designed, for the provision of public services; the implementation of these systems often requires the involvement of multiple organizations in a given government setting. Such implementation in developing countries -including the least developed ones- is associated with frequent failures (Gunawong et al., 2017).

The Least Developed Countries (LDCs), i.e. the 47 socio-economically most underdeveloped countries (UNCTAD, 2017) have started to embark on the implementation of e-government service projects that require the involvement of multiple organizations (United Nations, 2016). Those projects include for instance the implementation of one-stop e-government initiatives and enterprise content management (ECM) systems (Hughes et al., 2006; Bakunzibake et al., 2016). One-stop e-government and ECM require tackling 'socio-technical' system issues, for instance, making changes to internal processes, redesigning job and workflow and adjusting organizational structure for successful implementation (Hughes et al., 2006; Vom Brocke et al., 2014, Horne, 2014). However, there have been limited studies investigating 'socio-technical' system issues in Rwanda and in other LDCs as far as implementation of e-government is concerned.

Taking a socio-technical perspective, this paper seeks to answer the question of "What is the extent of socio-technical changes and effects in the implementation of e-government service-oriented initiatives in Rwanda?" Those changes and effects are explored during the period from January 2017 to May 2018. Rwanda is one of the LDCs (UNCTAD, 2017) which have recently embarked on implementations of serviceoriented projects, including one-stop e-government and ECM, spanning multiple agencies. Our interest in Rwanda case lies in the fact that it is the e-government leader among African LDCs (United Nations, 2018) and the findings on this case can inspire other similar contexts and inform practitioners in Rwanda and in another context as well as researchers. This study focuses on two service-oriented projects in Rwanda, the implementation of Enterprise Content Management (ECM) and one-stop egovernment.

\section{E-government implementation and socio-technical issues}

E-government implementation of service-oriented initiatives can be seen as a continuous process consisting of stages and activities that introduce changes (Meyers et al., 2012; Zmud et al., 1979). These changes can be defined in terms of the institutional transformation process that requires organizational change (Meijer et al., 2004). 
On the other hand, an organization in which the implementation of a programme or initiative takes place is viewed as a socio-technical system. Such a socio-technical system is comprised of two sub-systems, i.e. a 'social sub-system' and a technical subsystem (Bostrom et al., 1977). The technical sub-system is concerned with "the processes, tasks, and technology needed to transform inputs to outputs." On the other hand, the social sub-system is concerned with "the attributes of people (e.g., attitudes, skills, and values), the relationships among people, reward systems, and authority structures" (Bostrom et al., 1977, p. 17). Elements comprising the sociotechnical system, i.e., processes and tasks, people, structures, and technology, are seen to be interdependent as changes in one element can cause changes in another in such a 'socio-technical' system (Nograšek, 2011) and the outputs of the system are assumed to be "the result of joint interactions between these two systems" (Bostrom et al., 1977, p. 17). For example, this view of interdependence and interaction among constituent elements of a socio-technical system is echoed in Zmud et al.'s (1979) work that shows that changes in internal processes induce changes in the work process and hence changes in responsibilities of the employees. The required changes induced in an organization by 'planned' or 'designed' changes in technology or processes or in other aspects of that organization, are referred to as secondary changes. When these are not implemented, they result in secondary effects (Bostrom et al., 1977). Figure 1 depicts a socio-technical system in an organization implementing an e-government service-oriented project.

Figure 1

The socio-technical system in the implementation of e-government service-oriented initiatives

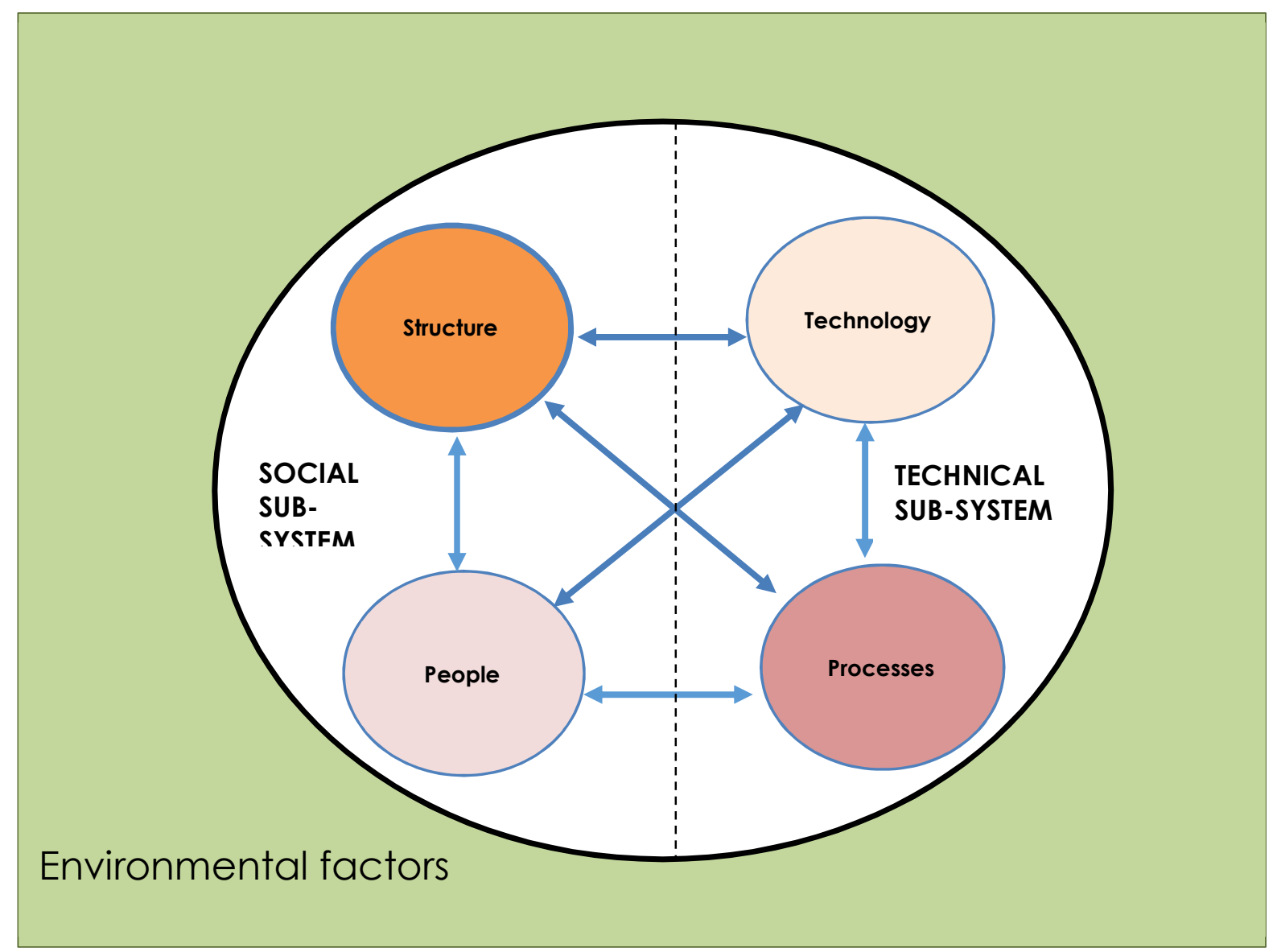

Source: Adapted from Bostrom et al. (1977) work 
The components comprising a socio-technical system are not made explicit in Bostrom et al.'s (1977) work. The socio-technical system of analysis in this paper consists of four aspects: people, structures, technology, and processes. A brief description of each of these follows.

- People. People are an integral part of any organization. The analysis should include people's attitudes, skills, values, beliefs and interactions, reward systems and authority structures. Aspects of government employees are under exploration in this study.

- Structure. The organisational structure is defined in different ways. According to Jacobides (2007), it is a foundation on which operating procedures rest. Pugh (1990) sees it as a framework, which defines how the allocation of tasks, coordination, and supervision are directed toward attaining organizational goals. It is also seen as a multidimensional construct consisting of formalization of procedures, standardization, and specialization of work in units, centralization/decentralization of control and job configuration in terms of hierarchical layers in an organization (Pugh et al., 1968). In the public sector, policies, rules, and regulations are viewed as part of the structure. Structural aspects of the socio-technical system being explored in this paper are those pertaining to government agencies.

- Technology. Technology is defined as "the application of scientific knowledge that enables manipulation of human surroundings for the practical purpose of meeting human desire" (Haines et al., 2006, p. 107). In this paper, the focus is on Information Technology, which is viewed as a set of hardware, software components, innovative procedures and applied knowledge used in public organizations. Specifically, the focus of this study is on changes in Information Technologies during the implementation of e-government service-oriented initiatives.

- Processes. A process is defined as "a structured, measured set of activities designed to produce a specified output for a particular customer or market" (Davenport, 1993, p. 5). It consists of specific inputs and outputs. A process, and of course tasks, consume resources (Suárez-Barraza, 2013) and may have a starting point an end or be continuous (Lee et al., 1998). Bititci et al. (1997) see tasks as elementary parts comprising a business process that produce an output. Being part of processes, tasks are viewed as underlying organizational activities in the work systems in this paper. Processes are classified into three categories of organizational processes: 1) main processes or core, primary or operational processes to achieve the goals of an organization; 2) management processes, carried out by the management to achieve its goals; and 3) support processes for the upkeep of the organization, e.g., taking care of staff (von Scheel et al., 2014). Note that in this paper, we subsequently use the term 'processes' instead of the term 'tasks' used by Bostrom et al. (1977). Processes are broader but of course, include tasks.

The aforementioned four aspects and their resulting interaction are viewed, in this paper, as core elements in organizations implementing e-government. As indicated in Figure 1, such a socio-technical system is embedded in an environment that can influence the system. Elements comprising such environments include political, financial, socio-economic, and stakeholder factors (e.g., citizens' needs and values). These environmental factors are beyond the scope of this paper.

The proponents of socio-technical thinking in e-government implementation include Damodaran et al. (2005), Dawes (2009), Gibreel et al. (2017) and Kompella (2017). For instance, Damodaran et al. (2005) pointed out that improved services by 
government agencies and underlying processes require "the development of sociotechnical sub-systems, combining technology and communication processes which meet the task needs of citizens and the procedural and legal requirements of local government" (p. 9).

Such implementation is characterized by higher e-government project failures (Mpinganjira, 2013; Gunawong et al., 2017). Those failures are attributed to factors related to political, social, technological, and organizational issues (Weerakkody, 2011). To Khan et al., (2011), e-government failures in the context of developing countries can be attributed to viewing information technology as the central element to achieve expected benefits but with less attention given to the organizational and social environments in which the technical system should operate. Tackling organizational and social issues for e-government implementation along with the implementation of ICT technical 'tool' systems can be an interesting phenomenon in the least Developed Countries (LDCs) where resources are scarcer. These issues call upon paying balanced attention to 'socio-technical' system issues necessary for successful implementation (Bostrom et al.'s, 1977); addressing these issues can cost less in LDCs instead of spending existing limited resources on systems, which would be costly to replace in future.

A number of studies, focusing to the e-government implementation issues in LDCs, which are part of the context of developing countries (UNCTAD, 2017), exists. For instance, Nkohkwo et al.'s (2013) literature review study categorized challenges impeding e-government implementation in the context of Sub-Saharan Africa (where most of LDCs are located) as financial, infrastructural, political, organizational, human, and socio-economic factors. Organizational issues, in the same study, were identified to be related to organizational structure, power distribution, prioritization of deliverables, organizational culture and coordination in that context (Nkohkwo et al., 2013). Specifically, Furuholt et al.'s (2018) empirical work identified that infrastructure, management and human-related challenges constraint implementation of egovernment services in Tanzania as one of the LDCs. In the same way, Rammea et al., (2017)'s study pointed out that organizational issues (e.g., government support, ICT skills, communication, and funding) are among the most prominent concerns in the implementation of e-government system for companies' registry in Lesotho. Likewise, Hoque et al.'s (2015) work identified challenges related to access to information and services in Bangladesh. In the context of Rwanda, Twizeyimana et al. (2018) categorized challenging issues constraining implementation of one-stop egovernment in the early stage as those pertaining to social inclusion, infrastructure, management, governance, language, and trust in the new system. On the other hand, Bakunzibake et al. (2016) identified that e-government practice of enterprise content management in Rwanda focused on the implementation of a technical tool with less attention to organization changes issues. In view of this illustrative review on the context LDCs, e-government research on that context have been more focusing on general issues with limited attention to the core 'socio-technical' system aspects (i.e., processes, technology, structures, people).

In other contexts, for instance, in the European member states, 'socio-technical' change examples include 29 good practices relating to the re-organization of backend processes and adjusting regulatory frameworks and policies for improving egovernment services (Millard et al., 2004). The study by Strejcek et al. (2003) echoes the same idea on how the harmonizing of legislation in the European Union member states has been one of the main challenges for e-government implementation to address since the year 2000. On the other hand, the development of e-government services in a number of developing countries, and specifically LDCs has hardly 
reached the stage of integration. Services in these contexts are less transactional than those in the context of developed countries (United Nations, 2014; United Nations, 2018); a number of developing countries still lagged behind developed ones when it came to services that had reached the stage of 'networked presence' according to the United Nations' (2014) survey report. Furthermore, tackling 'socio-technical' changes for e-government implementation in the context of developing countries is under-reported.

That paints a picture that attaining a reasonable level of integration of $e$ government systems is still needed in the context of developing countries and specifically in LDCs; implying that more organizational change taking into account core 'socio-technical' aspects (e.g., processes, people, organizational structure, technology, and their resulting interaction) is needed in that context. Furthermore, the brief literature review on LDCs in this section, illustrate that there is a paucity of a thorough investigation of the core 'socio-technical' issues as far as e-government the implementation is concerned

\section{Methods}

This is a qualitative case study. This approach was chosen to gain an understanding of the subject of research in a real-life setting (Benbasat et al., 1987). The study explores the extent of the changes and effects in the implementation of egovernment service-oriented initiatives in Rwanda in the period from January 2017 to May 2018. As for cases, it investigates two projects; the 'one-stop' e-government and ECM. Managers involved in these two projects were interviewed, who are the primary stakeholders in terms of both implementers and users. We also analyzed documents and online material related to the implementation of the two projects.

\section{Rwanda case}

The first case used in this study is the implementation of an Enterprise Content Management (ECM) system. The project started in 2010 (Office of the Auditor-general, 2016). According to the project coordinator, the actual ECM implementation into agencies started in 2012 in ministries. Later it was implemented in other agencies including those at the local government level. Today, implementations are still being carried out in new agencies (SM-RISA, personal communication, February 16, 2018). First, the system was deployed in all Rwandan ministries. Later, it was also rolled out in a number of other agencies at the central government level, all province headquarters, and all district agencies, amounting to 120 agencies nationwide. 'Document Tracking Management System' (DWMS) or e-mboni are the local names for the ECM system. The system allows users in agencies to share digital documents received in paper form from citizens, businesses and other agencies, according to the project coordinator. Currently, ECM is implemented in 110 public institutions (SM-RISA, personal communication, February 16, 2018).

The second project is an implementation of 'one-stop' e-government to provide a bundle of 100 services via a single government portal. It is called 'IREMBO,' meaning 'main entrance.' The project started in April 2014. The Government of Rwanda entered into a twenty-five-year public-private partnership, effective August 06, 2014, with Rwanda Online Platform Ltd, to build and operate an e-government platform to provide online public services. Rwanda Online Platform Ltd (ROPL), i.e. the contracted private company, Rwanda Information Society Authority (RISA) and the Ministry of Information Technology \& Communications (MITEC), are direct stakeholders in the implementation. The Ministry of Local Government, including a number of agencies 
at central government level and all thirty Rwandan districts, is a user and agency of one-stop e-government; these agencies also administer the process and provide public services via the online portal (MINECOFIN, 2017; the Republic of Rwanda, 2016).

The common element in the two case projects is that both are implemented by the central government. Furthermore, user agencies of their corresponding information systems are central government and local government agencies (e.g., all 30 Rwandan districts) which all administer both the processing of services in the backend and the provision of the same services (MINECOFIN, 2017).

Implementation of the ECM project is still ongoing in terms of making improvements, according to the project coordinator (SM-RISA, personal communication, February 16, 2018). The implementation of the one-stop e-government project is also still in progress according to the project coordinator at the Ministry of Information Technology \& Communications (SM-MITEC, personal communication, 13 February 2018). This study explores the extent of changes in people aspects, structures, technology, processes and effects of their resulting interaction in government agencies while implementing the two projects in the period from January 2017 to May 2018. This period was chosen to explore implementation issues that persisted in both projects, as there were prior related studies on two cases that we conducted before 2017. Seventeen months from January 2017 onwards were judged a reasonable time (not too long and not too short) to explore what happened retrospectively

\section{Data Collection}

The questionnaire used for conducting semi-structured interviews was devised from socio-technical theory (Bostrom et al., 1977) to identify issues related to changes in processes and tasks, technology, and organizational structure and people aspects. Furthermore, the aspect of regulatory framework identified in the literature was added to the aspects of the questionnaire. The questionnaire consisted of 25 questions on implementation of the projects of enterprise content management and one-stop egovernment, respectively, in Rwanda.

The main focus was on aspects of Processes, Technology, People, Organisational Structure, Legal framework and policies and were centered on the themes of:

- Main activities of the implementation in the period from January 2017 up to May 2018?

- Changes that took place in both projects and in government agencies that period and why those changes

- Challenges that were faced in the implementation, the outcome of implementation in agencies and

- Plans

Thirteen semi-structured interviews were conducted from December 2017 to May 2018 in 'Kinyarwanda' (i.e., local language) for both projects. The first author interviewed managers in eight agencies. Four agencies (i.e., three government ones and a private company) implement the projects at the central government level. The other four agencies (at the local government level) are among the users of the respective government information systems in the two projects. More information on the agencies and participants is presented in Table 1. Each interview took 30 minutes on average. Regarding choosing individual participants from different agencies for the study, the criteria were based on the role they play in the implementation of the projects and in the usage of the products thereof 
Table 1

Agencies and Interview participants: case IREMBO and ECM projects

\begin{tabular}{|c|c|c|c|c|c|}
\hline Agency & $\begin{array}{l}\text { Agency } \\
\text { type }\end{array}$ & $\begin{array}{l}\text { Respondent } \\
\text { Role }\end{array}$ & $\begin{array}{l}\text { Respondent } \\
\text { Codes }\end{array}$ & $\begin{array}{l}\text { Respondent } \\
\text { Project } \\
\text { Involvement }\end{array}$ & $\begin{array}{l}\text { No of } \\
\text { participants }\end{array}$ \\
\hline $\begin{array}{l}\text { Ministry of } \\
\text { Information } \\
\text { Technology \& } \\
\text { Communications } \\
\text { (MITEC) }\end{array}$ & $\mathrm{CG}^{*}$ & $\begin{array}{l}\text { Senior } \\
\text { manager }\end{array}$ & SM-MITEC & IREMBO & 1 \\
\hline $\begin{array}{l}\text { Rwanda } \\
\text { Information } \\
\text { Society (RISA) }\end{array}$ & CG* & $\begin{array}{l}\text { Senior } \\
\text { manager }\end{array}$ & SM-RISA & $\mathrm{ECM}$ & 1 \\
\hline $\begin{array}{l}\text { Rwanda Online } \\
\text { Platform Ltd } \\
\text { (ROPL) }\end{array}$ & Private* & $\begin{array}{l}\text { Senior } \\
\text { manager } \\
\text { Medium level } \\
\text { manager }\end{array}$ & $\begin{array}{l}\text { SM-ROPL } \\
\text { MLM-ROPL }\end{array}$ & IREMBO & 2 \\
\hline $\begin{array}{l}\text { Rwanda Land } \\
\text { Management and } \\
\text { Use Authority } \\
\text { (RLMUA) }\end{array}$ & $\mathrm{CG}^{*}$ & $\begin{array}{l}\text { Senior } \\
\text { manager }\end{array}$ & SM-RMUA & IREMBO & 1 \\
\hline Kicukiro District & $\mathrm{LG}^{*}$ & $\begin{array}{l}\text { Medium level } \\
\text { managers (2) }\end{array}$ & $\begin{array}{l}\text { MLM1-LG } \\
\text { MLM2-LG }\end{array}$ & $\begin{array}{l}\text { IREMBO \& } \\
\text { ECM }\end{array}$ & 2 \\
\hline Ruhango District & $\mathrm{LG}^{*}$ & $\begin{array}{l}\text { Senior } \\
\text { manager } \\
\text { Medium level } \\
\text { manager }\end{array}$ & $\begin{array}{l}\text { SM1-LG } \\
\text { MLM3-LG }\end{array}$ & $\begin{array}{l}\text { IREMBO \& } \\
\text { ECM }\end{array}$ & 2 \\
\hline Huye District & LG* & $\begin{array}{l}\text { Senior } \\
\text { manager }\end{array}$ & SM2-LG & $\begin{array}{l}\text { IREMBO \& } \\
\text { ECM }\end{array}$ & 1 \\
\hline Gakenke District & $\mathrm{LG}^{*}$ & $\begin{array}{l}\text { Senior } \\
\text { manager } \\
\text { Medium level } \\
\text { managers (2) }\end{array}$ & $\begin{array}{l}\text { SM3-LG } \\
\text { MLM4-LG } \\
\text { MLM5-LG }\end{array}$ & $\begin{array}{l}\text { IREMBO \& } \\
\text { ECM }\end{array}$ & 3 \\
\hline
\end{tabular}

*Note: CG: Central government, Private: Private company, LG: Local government Source: Authors' work

Government documents, internal documents and online material related to the implementation of the two projects and usage of the corresponding information systems were also consulted, as shown in Table 2. 
Table 2

Consulted documents and materials related to ECM and 'Irembo' projects

\begin{tabular}{|c|c|c|}
\hline Document name & Project & Reference/ Type \\
\hline $\begin{array}{l}\text { Service Delivery Joint } \\
\text { IMIHIGO FY 2017-2018 }\end{array}$ & IREMBO & (MINECOFIN, 2017) \\
\hline $\begin{array}{l}\text { Development and } \\
\text { Deployment of Rwanda's } \\
\text { Single Integrated e- } \\
\text { government Platform }\end{array}$ & IREMBO & (Republic of Rwanda, 2016) \\
\hline $\begin{array}{l}\text { Eliminate bureaucracy from } \\
\text { land registration }\end{array}$ & IREMBO & (Igihe Ltd, 2017) \\
\hline District benchmarking report & IREMBO & Internal document \\
\hline $\begin{array}{l}\text { Document Tracking \& } \\
\text { Workflow Management } \\
\text { System Report, April } 2014\end{array}$ & ECM & Internal document (RDB, 2014) \\
\hline $\begin{array}{l}\text { Rwanda Civil Registration } \\
\text { and Vital Statistics Systems }\end{array}$ & IREMBO & $\begin{array}{l}\text { (National Institute of Statistics of Rwanda, } \\
\text { 2016) }\end{array}$ \\
\hline $\begin{array}{l}\text { Performance audit on } \\
\text { utilization of document } \\
\text { tracking and workflow } \\
\text { management system }\end{array}$ & ECM & (Office of the Auditor-general, 2016) \\
\hline $\begin{array}{l}\text { Records and archives } \\
\text { management policy }\end{array}$ & ECM & (MINISPOC, 2012) \\
\hline $\begin{array}{l}\text { Service charter at district } \\
\text { level }\end{array}$ & IREMBO & (MINALOC, 2015) \\
\hline $\begin{array}{l}\text { Presidential Order } N 25 / 01 \text { of } \\
09 / 07 / 2012 \text { establishing the } \\
\text { list of fees and other Charges } \\
\text { levied by decentralized } \\
\text { entities and determining their } \\
\text { thresholds }\end{array}$ & IREMBO & (Republic of Rwanda, 2012) \\
\hline $\begin{array}{l}\text { 'Mutuelle' subscribers to use } \\
\text { IDs to access healthcare }\end{array}$ & IREMBO & (The New Times, 2018a) \\
\hline Land transfers go online & IREMBO & (The New Times, 2018b) \\
\hline $\begin{array}{l}\text { New ICT law embodies data } \\
\text { privacy protection }\end{array}$ & $\begin{array}{l}\text { IREMBO \& } \\
\text { ECM }\end{array}$ & (The New Times, 2018c) \\
\hline
\end{tabular}

Source: Authors' work

\section{Data Analysis}

This paper aims to answer the question: "What is the extent of socio-technical changes and effects in the implementation of e-government service-oriented initiatives in Rwanda?"

In order to answer this question, empirical data were analyzed following a template analysis method in which themes can be formed from literature or theory (Blair, 2015). The themes used in this paper are adapted from Bostrom et al.'s (1977) work as in Table 3. These were chosen as themes to describe a number of designed (planned) or intended changes, which were implemented. From the same work, we also deduced a fifth theme "secondary effects" which is used to describe unintended or indirect 
(unplanned) effects that took place or potential effects that would result from the interactional relationship among aspects of the four dimensions (Bostrom et al., 1977).

Table 3

Themes used for data analysis

\begin{tabular}{ll}
\hline No. & Theme \\
\hline 1 & Technology \\
2 & Processes \\
3 & People \\
4 & Organizational Structure \\
\hline 5 & Secondary effects \\
\hline
\end{tabular}

Source: Authors' work

Those themes were chosen as appropriate in relation to providing enough perspectives towards answering the research question.

\section{Results}

This study set out to explore the extent of changes and effects occurring during the implementation of e-government service-oriented initiatives in Rwanda in the period from January 2017 to May 2018. The study also identifies the corresponding effects. The two cases, Enterprise Content Management (ECM) and the one-stop project in Rwanda were studied from a socio-technical perspective; interview data, documents, and online material were analyzed as described the Data Analysis section above.

\section{The ECM case}

- Processes. Changes in work processes that took place from January 2017 to February 2018 include sharing and working digitally on internal memos, leave requests for and requisitions of office stationery and transport requests in government agencies, according to the national project coordinator an interview (SM-RISA, personal communication, February 16, 2018).

Regarding potential changes in processes, the ECM project coordinator pointed out, in an interview, that government employees will be able to sign documents digitally in future after implementation of digital signature functionality. She added that employees among different government agencies would be able to exchange documents digitally among themselves (SM-RISA, personal communication, February 16, 2018).

- Technology. According to the project coordinator, the ECM technical system is implemented in 110 agencies out of the planned 120 at central and local government levels. She indicated that the software was procured from an Indian company by RDB (i.e., a central government agency) and was customized to local needs by local IT staff together with consultants. As part of intended changes, the functionalities of the system to allow staff to work on, share and store documents digitally were being implemented in new agencies (e.g., RISA, and Ministry of Youth). Planned changes in future include incorporating a digital signature functionality and integrating individual ECM systems of agencies so that these agencies can interchange documents digitally. She mentioned this in an interview (SM-RISA, personal communication, February 16, 2018). The technical system was procured and adapted to be deployed at both central and local government. According to the national project coordinator, ICT officers are the contact persons and the ones who 
inform the central coordination office about issues concerning ECM in their agencies (SM-RISA, personal communication, February 16, 2018)

- People. Changes in people aspects (mindset, skills, etc.) took place via a number of training sessions that were conducted for government employees to use the ECM technical system. The project coordinator indicated that from March 2017 to January 2018, staff in 11 agencies were trained to increase their skills and to change people's mindsets in order to reduce resistance to change and adopt ECM (SM-RISA, personal communication, February 16, 2018). The project coordinator, an in an interview, pointed out that she planned to conduct more training, engage more agencies and raise awareness about ECM (SM-RISA, personal communication, February 16, 2018). On the same issue of training of staff, a respondent indicated that his district had one session of training on the use of ECM in June 2017 (MLM4-LG, personal communication, March 28, 2018).

- Organizational structure. The ECM system was designed according to existing or 'as-is' workflows of the agencies in the period of our investigation, i.e. January 2017 to May 2018. For example, we learned in an interview that the design of the ECM system for new government agencies such as the Ministry of Youth and the Rwanda Information Society (RISA) that began towards the end of 2017 followed the structure instituted for the new agencies (SM-RISA, personal communication, February 16, 2018). The static nature of the workflow of agencies after ECM implementation was echoed by managers in three government agencies at the district level in interviews (SM2-LG, personal communication, February 16, 2018; MLM1-LG, personal communication, December 12, 2017; SM1-LG, personal communication, January 29, 2018). ECM was and adapted to the existing workflow of agencies (SM-RISA, personal communication, February 16, 2018).

On the other hand, internal policies were put in place in one agency. For instance, a manager in an urban district indicated, in an interview, that "ECM was successful in their agency because of instructions put forth in meetings by the Mayor that everybody [employees] should use the system [ECM] and the central secretary should send scanned copies to staff and not hand over any hard copies to any of them". The manager mentioned that, previously, staff used to go to pick up documents to process from the secretary, but after the new instructions, nobody dared to go and pick up hard copies (MLM1-LG, personal communication, January 19, 2018).

- Secondary effects. A number of secondary effects resulting from intended changes and lack thereof were identified. For instance, a senior manager in a district agency pointed out challenges pertaining to tasks, technology and economic use of resources at the workplace: 'the problem with e-mboni [the ECM system] is that it requires printing as well as signing manually; we still consume paper. The amount of paper we use has not really been reduced' (SM1-LG, personal communication, January 29, 2018). Another respondent, in an interview, mentioned an issue regarding the unsatisfactory speed of operations and low usage of the ECM system in relation to technical design. He indicated: 'it requires time to scan documents and to forward them to those who handle them, but the issue is that those who are to process them mostly prefer working with hard copies due to the problem of signing which is not possible electronically.' The respondent pointed out that usage of the system is low in their agency (MLM3-LG, personal communication 22 February 2018). The challenges mentioned here constitute unplanned issues or effects resulting 
from the interaction between ECM technology, processes and people (i.e., employees in government agencies).

Furthermore, it was noted in an interview in one agency, that ECM implementation brought a slight change in the work system to some extent. It was observed that in one district, the assistant to the Legal advisor and Notary officer was leaving her job, temporarily, to help a central secretary and switching back and forth depending on the number of documents to work on in the ECM system (SM2-LG, personal communication, December 21, 2017). This unplanned issue resulting from the interaction between technology, tasks, and people at the workplace can result in secondary effects such as job dissatisfaction.

Moreover, internal policies and lack of them influenced the ECM implementation. For instance, the existence of an internal policy was claimed to have contributed to the successful implementation of ECM in one agency. However, instructions to use the ECM system in that district were given in meetings and no corresponding document was found. On the other hand, a senior manager in another district mentioned, in an interview, that the number of users of the ECM system was reduced because there was no policy related to ECM in their agency. To address this issue, the manager indicated that they were planning to have such a policy (SM3-LG, personal communication, January 15, 2018). These are unplanned issues related to the interaction between structures and people aspects in the design of the ECM.

Unplanned issues in technology, in the work processes, and in the organizational structure for example, putting in place internal policies and regulations can result in adverse effects that can lead to low usage of ECM or even failure. For instance, in an interview, the ECM coordinator at the national level indicated that about half of the agencies do not use the system due to issues including licenses, not requested or updated (SM-RISA, personal communication, February 16, 2018). Likewise, an earlier report showed that the system was implemented in 116 agencies to a total cost of USD $2,681,112$, as up to April 2016 , but only about $30 \%$ were actually using the system; a considerable number of agencies with valid licenses did not use the system (Office of the Auditor-general, 2016).

\section{Case IREMBO}

- Processes. In the period from January 2017 to May 2018, change in the work processes especially for service clerks resulted from starting the issuing a selfservice for online birth certificates, marriage certificates, and full identity certificates to residents in the urban district of Gasabo. According to the national e-government coordinator at the Ministry of Information Technology and Communications, in an interview, such self-service pilot project was undertaken from November 2017. Prior to this, service seekers had to pick up the certificates physically from service clerks at sector offices; giving more work to clerks. (SM-MITEC, personal communication, 13 February 2018).

Changes in the work processes also occurred at district offices in the land units in Rwanda: the service of transfer of land titles by sale was re-designed in order to provide the corresponding certificates in 7 days instead of months (Igihe Ltd, 2018). Such redesign was achieved by bypassing district offices: an application is made via the IREMBO platform and forwarded directly to the land agency operating at provincial and national level, i.e. Rwanda Land Management and Use Authority (RLMUA) (The New Times, 2018b). However, it is unclear how the responsibilities of employees who worked on this service at the district level (e.g., billing officers and district land officers) were adjusted. 
Other changes are expected to occur in the work system at health centers in the unit of mutual health insurance. Preparations to provide online services to register and pay for community-based health insurance via the IREMBO portal for citizen are being made. These services were made available on July 1, 2018 (The New Times, 2018a).

Furthermore, changes are expected in the land agency operating at the provincial and national level and in the local government agencies (i.e., districts agencies) as responsibilities of their staff who process land services would change. This would happen because of the existing plan of transferring land services to the local government level. A senior manager in the land agency at the national level indicated that the local government would take over from July 2018 (Igihe Ltd, 2017; SM-RMUA, personal communication, 08 February 2018).

- Technology. Among the changes in technology in the period from January 2017 to May 2018, we noted that Digital signature was implemented in onestop services. It was used for the provision of the self-services related to online birth certificates, marriage certificates, and full identity certificates according to a respondent in an interview (SM-MITEC, personal communication, 13 February 2018).

- People. Changes were introduced via training to government employees on the provision of one-stop e-government services to the public. The training includes the one conducted for civil registrars in January 2018. This training was organized on various issues including the Irembo project-by-project partners such as the Ministry of Local Government (MINALOC), the National Identity Agency (NIDA), and RwandaOnline (MINALOC, 2018). A governance officer in one district indicated that sector land managers and civil registrars in his district received training in November 2017 and this increased the provision of 'Irembo services' in the benchmark ranking (MLM2-LG, personal communication, 27 April 2018). However, his counterpart in another district indicated that through service clerks in this district had been trained to use Irembo in early 2017, performance was not yet good due to issues of poor internet access (MLM5LG, personal communication, 9 May 2018). Again, in relation to training employees, the Rwanda Education Board (REB) trained teachers so that they could help their students register online for national exams (The New Times, $2018 d$ ). Via such training sessions related to one-stop e-government, changes in skills, behavior, and mindset among employees will occur; these are expected to instill positive changes in the work system.

- Organizational structure. Changes in the regulatory framework as part of the organisational structure include the enactment of ICT law, including provisions on privacy and data protection. Among other elements, the law was enacted to regulate ICT-based communications including exchanges in the provision of public services via the 'one-stop' platform (The New Times, 2018c). In this way, for example, the law is expected to change the way government employees, in their duties, behave and act on matters related to ICT-based information and communications compared to the time before the law.

In relation to other expected changes, the Prime Minister's Order N No115/03 of 08/04/2016 determining the Structure of the Manual of Administrative Procedures in Public Service stipulates that, in Article 3, "Every public institution shall put in place and use a manual of administrative procedures customized to the institutional organisation"' (Office of the Prime Minister, 2016, p. 57). Moreover, documents reflecting the revised responsibilities of employees after the introduction of the onestop e-government initiative were not available from agencies. For instance, existing service charters (e.g., MINALOC, 2015) still indicate that the service of transfer of land 
titles is still provided at district level although district offices are currently bypassed and such services are supplied via the 'Irembo portal' and the same service is processed by the Land Agency at the provincial and national levels.

- Secondary effects. In one agency, a problem of increased workload was identified, due to either technical problems or redistribution of work. A land manager said 'when we have a lot of service seekers it is very difficult for a clerk to scan their documents with slow scanners which scan a page at a time' (MLM3-LG, personal communication, 19 January 2018). This issue can be attributed to technology, specifically ICT infrastructure, when people interact with hardware in the workplace, or it can be attributed to unbalanced work distribution or to a job redesign issue. Internet connection was also a problem in one sector office; an employee had to travel from his sector office and go to work at the district headquarters, sometimes outside office hours, in order to get good internet access (SM1-LG, personal communication, 04 January 2018). The former and latter issues can lead to side effects such as low satisfaction among staff.

Potential secondary effects such as work overload and dissatisfaction of some staff, and a light load for others, resulting, for example, from a limited adjustment of job responsibilities observed among some government employees as the new egovernment services emerge (e.g. online birth certificates, marriage certificates, full identity certificates, and health insurance services). However, there is yet no available information indicating how job responsibilities were adjusted, and related plans are not clear.

In relation to that, issues pertaining to re-defining and adjusting structures as the implementation of one-stop e-government advances were observed. For instance, due to limited harmonization of operational procedures and requirements for some services, unanticipated effects such as service dissatisfaction, the tendency to mistrust, and even quarrels can occur and affect the working environment. These would affect service seekers and relationships between service seekers and service providers. The issue of limited harmonization can be concluded from a mismatch in service information (e.g., on service cost, service delivery time) currently observed in different public information sources, for example, citizen charter documents on some district websites (e.g. MINALOC, 2015), 'Irembo' portal, and government public documents (e.g. Republic of Rwanda, 2012).

Regarding the issue of reviewing structures, a need for a conducive legal framework and policies to integrate civil registration and other national systems on which one-stop e-government relies were identified. This implies enabling the interoperability of the databases of Civil Registration and Vital Statistics (CRVS) and the National Population Registry system (National Institute of Statistics of Rwanda, 2016). Limited attention to these issues could result in side effects such as inefficiency in the work system of agencies and could continue to hamper the quality of services in some way.

Furthermore, changes are expected in the land agency operating at the provincial and national level and in the local government agencies (i.e., districts agencies) as responsibilities of their staff who process land services would change. This would happen because of the existing plan of transferring land services to the local government level. A senior manager in the land agency at the national level indicated that the local government would take over from July 2018 (Igihe Ltd, 2017; SM-RMUA, personal communication, 08 February 2018). However, at RLMUA there is no document indicating how the responsibilities of staff are going to change (SMRMUA, personal communication, 08 February 2018). 


\section{Discussion and Conclusion}

This paper explores the extent of the changes and their effects resulting from the implementation of e-government service-oriented initiatives in Rwanda in the period from January 2017 to May 2018 for two cases: the ECM and the one-stop egovernment initiatives. A number of changes and effects were identified in both cases.

For instance, regarding the ECM case, changes were made in technology implementing new ECM functionalities, and ECM was rolled out in new agencies with a hope to change work processes in a better way. Other changes were made in people aspects via training, in organizational structure in few agencies in terms of policies. However, the number of agencies, which adopted ECM, was low in relation to expectations. A loose fit between technology, processes, and people aspects was found; some users viewed the ECM system as a system, which did not provide the expected advantages, such as easing workloads. In some instances, users wanted to do manual paperwork instead of using the ECM system. In relation to this, other users found that ECM implementation had failed to reduce the consumption of paper, which was expected. Furthermore, users attributed low usage of ECM in their agencies to technical issues such as not being able to sign digitally. Likewise, the lack of fit between people aspects and structures was also observed; for instance, low usage of ECM system was also associated with lack of internal policies in some agencies. Let us note that the issue of low usage of ECM systems in Rwandan government agencies had been noticed earlier on (Office of the Auditor General, 2016).

Concerning organizational structure, the issue of static workflow during ECM implementation was identified, and no provision was made to adjust organizational workflow and job responsibilities in the ECM system design or re-design. A problem of lack of internal policies was also identified among most agencies. Those elements show that ECM implementation is superimposed over existing organizational structures in the studied agencies.

Furthermore, it was identified that future developments focus on technical aspects including the deployment of digital signatures and the integration of ECM technical systems among agencies for ease of interchange of digital documents.

Summing up the findings on the ECM case, the focus on implementation is more on the technical sub-system, as attention is paid more to tasks and technology than to social aspects. The focus on technical aspects is fine, but there is an apparent need for increased attention to the social sub-system (people aspects and structures) of organizations for a successful implementation. The current findings are very similar to those in Bakunzibake et al.'s (2016) work, which identified that more focus was being put on the implementation of the technical system than balancing this with issues related to handling organizational changes.

In relation to the case of the one-stop e-government initiative, a number of planned (i.e., designed) changes were made. These include changes in the technical subsystem in terms of introducing new online services-the changes implying re-design of job responsibilities and reviewing organizational structures. Other changes made were related to the social sub-systems of government agencies, for instance, changes in people aspects via training of employees and those in the regulatory framework (structures) in terms of enacting an ICT law.

Even though a number of changes were introduced in the technical sub-system, designed in response to new services, the most prevalent issue identified concerns adjustment of organizational structure, which is lacking; this is an issue pertaining to the social sub-system. Government employees in undertaking their daily operations 
would need to be guided and follow a well-defined and coherent organizational structure. However, the current organizational structure is not fully adjusted to the new designed changes in the technical system. It is unclear how job responsibilities will be adjusted in relation to new services, as there is no document on that in place, and there is at least some inconsistent public information on some services (e.g., service cost, service time). In relation to this, there is an apparent need for revised organizational structures and harmonizing the related information. For instance, addressing the issue would contribute to mitigating the problem of the heavy workload of civil registrars, already identified in Rwanda two years ago (National Institute of Statistics of Rwanda, 2016). A delay in addressing this issue would create an imbalance in workload among staff in some agencies and unfair reward systems for some time. Another organizational structure issue we identified was a need to have a conducive regulatory framework to help integrate civil registration and other national systems. These systems are integral parts of Rwanda's e-government, and their integration is mandatory for better services. In addition, a delay in addressing it would hamper the quality of services to some extent as these may not be fully transactional.

Another issue identified is related to the interaction between people and technology. Some employees were having difficulties carrying out their duties due to poor internet connection or due to ill-suited hardware.

The current findings on the Rwanda case, regarding the imbalance between the social and technical systems of local government agencies in the case of ECM implementation as well as the identified issue of organizational structure in the case of one-stop e-government, can be explained by a number of implementation design issues. These are related to how 'designers' (systems analysts, users, top managers, systems designers...) view their organizations, their members and the functions of the interventions to be implemented (Bostrom et al., 1977):

For instance, procuring ECM software system by a central government agency, adapting the system to existing workflow of agencies with assumptions by ECM project coordination that potential users in the local and the central government will adopt it if training is conducted for them, all these are related to Systems Designer's Implicit Theories' in Bostrom et al.'s (1977) work.

It can also be observed that that 'designers' with ICT background were the ones who had been assuming more responsibilities in ECM implementation (as well as in the 'Irembo' initiative in its early stages). Having mainly technical people such as ICT officers being those responsible for reporting ECM issues in their agencies would involve the management of local government to a lesser extent; such management would be less responsible. This is termed as 'Systems Designer's Concept of Responsibility' (Bostrom et al., 1977). Responsibility should also be assumed by senior managers. It seems that ECM implementation is not carried out by senior management in most agencies at local government level but is instead left to technical staff. Such a phenomenon of involving a small group of designers is known as 'Limited Design Referent Group' concept in (Bostrom et al., 1977).

Furthermore, current findings can be explained by what took place at early stages in both projects. In the case of the 'Irembo' initiative, technical implementation was given priority ahead of the concrete planning of organizational issues such as adjustments in work processes and in organizational structure (the Republic of Rwanda, 2016). In the case of ECM, the primary goals of ECM designers were centered on improving efficiency in administrative processes and improving accountability and transparency, all pertaining to the technical sub-system of the organization (the Republic of Rwanda, 2015). However, goals related to improving the quality of working life coupled with the social sub-system cannot be traced in the project documents. 
To conclude, the findings on the ECM case paint a picture of a need for a greater fit between the technical and social sub-systems in organizations; a large gap is indicated by a number of secondary effects. Addressing issues pertaining to the social sub-system would make it possible to realize designed changes in the technical subsystem. This especially requires tackling existing issues arising when people use the ECM technical system and addressing issues related to internal policies and workflow.

Likewise, in the case of the 'Irembo' initiative, significant issues were found in the social system; there is a need for adjusting the organisational structure, and harmonizing the related public service information. However, as the administrative process would be guided by a coherent organizational structure, this can also be a sign of imbalance between technical and social sub-systems in the work systems of organizations. In relation to organizational structure, there is also an apparent need to establish a conducive regulatory framework to integrate systems and thus provide better working systems in agencies as well as improved services. An issue related to necessary improvements in ICT infrastructure was also identified. If these issues not addressed, the imbalance between the technical sub-system and social sub-system in the working environment of agencies will widen.

Practical implications associated with the empirical findings of this paper are that those findings can help e-government practitioners in Rwanda and in similar contexts to improve implementation processes of e-government services; the findings could inspire them in elaborating further plans towards balancing technical and social aspects for better services.

The present study acknowledges that data was collected from only four of 30 districts of the Rwanda local government, which are users of the 'Irembo' and ECM systems; further investigation is recommended at least in other districts to gain more insights on how implementation of e-government services can be further improved in Rwanda from a socio-technical perspective.

\section{References}

1. Bakunzibake, P., Grönlund, A., Klein, G.O. (2016), "E-Government Implementation in Developing Countries: Enterprise Content Management in Rwanda", in 15th IFIP Electronic Government (EGOV) / 8th Electronic Participation (ePart) Conference, Guimaraes, Portugal, IOS Press, pp. 251-259.

2. Benbasat, I., Goldstein, D. K., Mead, M. (1987), "The Case Research Strategy in Studies of Information Systems", MIS Quarterly, Vol. 11, No. 3, pp. 369-386.

3. Bititci, U. S., Muir, D. (1997), "Business Process Definition: A Bottom-Up Approach", International Journal of Operations and Production Management, Vol. 17, No. 4, pp. 365374.

4. Blair, E. (2015), "A reflexive exploration of two qualitative data coding techniques", Journal of Methods and Measurement in the Social Sciences, Vol. 6, No.1, pp. 14-29.

5. Bostrom, R. P., Heinen, J. S. (1977), "STS Perspective MIS Problems and Failures: A SocioTechnical Perspective PART I: THE CAUSES By: Robert P. Bostrom", MIS Quarterly, Vol. 1, No. 3, pp.17-32.

6. Damodaran, L., Nicholls, J., Henney, A., Land, F., Farbey, B. (2005), "The contribution of sociotechnical systems thinking to the effective adoption of e-government and the enhancement of democracy", The Electronic Journal of e-Government, Vol. 3, No. 1, pp. $1-12$.

7. Davenport, T. H. (1993), Process innovation: reengineering work through information technology, Boston, Harvard Business School Press.

8. Dawes, S., S. (2009), "Governance in the digital age: a research and action framework for an uncertain future", Government Information Quarterly, Vol. 26, No. 2, pp. 257-264.

9. Furuholt, B., Saeb $\varnothing, \varnothing$. (2018), "The role telecentres play in providing e-government services in rural areas: A longitudinal study of Internet access and e-government services in 
Tanzania", The Electronic Journal of Information Systems in Developing Countries, Vol. 84, No. 1, pp. 1-14.

10. Gibreel, O., Hong, A. (2017), "A Holistic Analysis Approach to Social, Technical, and SocioTechnical Aspect of E-Government Development", Sustainability, Vol. 9, No. 12.

11. Gunawong, P.,Gao, P. (2017), "Understanding e-government failure in the developing country context: a process-oriented study", Information Technology for Development, Vol. 23, No. 1, pp. 153-178.

12. Haines, J. D., Sharif, N. M (2006), "A framework for managing the sophistication of the components of technology for global competition", Competitiveness Review: An International Business Journal, Vol. 16, No. 2, pp. 106-121.

13. Hoque, M. R., Sorwar, G. (2015), "ICT Based E-Government Services for Rural Development: A Study of Union Information and Service Centre (UISC) in Bangladesh", The Electronic Journal of Information Systems in Developing Countries, Vol. 71, No. 1, pp. 1-19.

14. Horne, S. B. (2014), "Identifying Key Success Factors for the Implementation of Enterprise Content Management Systems", University of North Texas, available at:

https://digital.library.unt.edu/ark:/67531/metadc699882/m2/1/high_res_d/dissertation.pdf (21 May 2018).

15. Hughes, M., Scott, M., Golden, W. (2006), "The role of business process redesign in creating e-government in Ireland", Business Process Management Journal, Vol. 12, No. 1, pp. 76-87.

16. Khan, G. F., Moon, J., Park, H. W., Swar, B., Rho, J. J. (2011), "A socio-technical perspective on e-government issues in developing countries: a scientometrics approach", Scientometrics, Vol. 87, No. 2, pp. 267-286.

17. Kompella, L. (2017), "E-Governance systems as socio-technical transitions using multi-level perspective with case studies", Technological Forecasting and Social Change, Vol. 123, pp. 80-94.

18. Igihe Ltd (2017), "Eliminate bureaucracy from land registration-Biruta advises new minister", available at:

http://www.en.igihe.com/news/eliminate-bureaucracy-from-land-registration.html

(27 May 2018).

19. Igihe Ltd (2018), "Rusizi: Abaturage mu cyizere ko batazongera kwiruka igihe kirekire ku cyangombwa cy' ubutaka cya burundu", available at:

http://igihe.com/ubukungu/article/rusizi-abaturage-mu-cyizere-ko-batazongera-kwirukaigihe-kirekire-ku-cyangobwa (25 June 2018).

20. Jacobides, M. G. (2007), "The inherent limits of organizational structure and the unfulfilled role of hierarchy: Lessons from a near-war", Organization Science, Vol. 18, No. 3, pp. 455477.

21. Lee, R. G., Dale, B. G. (1998), "Business process management: a review and evaluation", Business Process Management Journal, Vol. 4, No. 3, pp. 214-225.

22. Luna-Reyes, L. F., Zhang, J., Gil-García, J. R., Cresswell, A. M. (2005), "Information systems development as emergent socio-technical change: A practice approach", European Journal of Information Systems, Vol. 14, No. 1, pp. 93-105.

23. Meijer, A., Zouridis, S. (2004), "E-government as institutional transformation", in KhosrowPour, M. (Ed.), Innovations through information technology, Hershey, PA: Idea Group, pp. 565-568.

24. MINALOC (2015), "Service Charter", available at: http://www.kicukiro.gov.rw/index.php?id=163 (27 December 2017).

25. MINALOC (2018), "Civil registration officers wOw to deliver quality service", available at: http://minaloc.gov.rw/index.php?id $=469 \& t x$ ttnews\%5Btt news\%5D $=585 \& \mathrm{cHash}=4 \mathrm{~d} 0 \mathrm{df} 1 \mathrm{f}$ b086043db9cc0327a767bfa40 (12 July 2018).

26. MINECOFIN (2017), "Service Delivery Joint IMIHIGO FY 2017-2018", available at: http://www.minecofin.gov.rw/fileadmin/templates/documents/NDPR/Imihigo/201718/Joint/Service Delivery.pdf (05 February 2018).

27. MINISPOC (2012), "Records and archives management policy", available at: https://www.minispoc.gov.rw/fileadmin/templates/Documents/cabinetgor records_management_policy.doc (21 June 2018). 
28. Millard, J., Iversen, J. S., Kubicek, H., Westholm, H., Cimander, R. (2004), "Reorganisation of government back-offices for better electronic public services - European good practices (back-office reorganisation)", in 4th European conference on eGovernment, Dublin, Ireland.

29. Mpinganjira, M. (2013), "E-government project failure in Africa: Lessons for reducing risk", African Journal of Business Management, Vol. 7, No. 32, pp. 3196-3201.

30. Meyers, D. C., Durlak, J. A., Wandersman, A. (2012), "The quality implementation framework: a synthesis of critical steps in the implementation process", American Journal of Community Psychology, Vol. 50, No. 3-4, pp. 462-480.

31. National Institute of Statistics of Rwanda (2016), "Rwanda Civil Registration and Vital Comprehensive Assessment Final Report Volume I National Institute of Statistics of Rwanda", available at: https://www.unicef.org/rwanda/RWA_resources_crvscafinal.pdf (21 January 2017).

32. Nkohkwo, Q. N. A., Islam, M. S. (2013), "Challenges to the successful implementation of egovernment initiatives in Sub-Saharan Africa: A literature review", Electronic Journal of eGovernment (EJEG), Vol. 11, No. 1, pp. 253-267.

33. Nograšek, J. (2011), "Change management as a critical success factor in e-government implementation", Business System Research, Vol. 2, No. 2, pp. 13-24.

34. Office of the Auditor-general (2016), "Performance audit on utilization of document tracking and workflow management system", available at:

http://www.oag.gov.rw/fileadmin/user_upload/Performance_Reports/UTILIZATION_OF_D

OCUMENT_TRACKING_AND_WORKFLOW_MANAGEMENT_SYSTEM-_E-

MBONI_REVIEW_OF_RDB_IT_GENERAL_CONTROLS.pdf (19 September 2018).

35. Office of the Prime Minister (2016), "Prime Minister's Order No115/03 Of 08/04/2016 Determining The Structure of The Manual Of Administrative Procedures In Public Service, MIFOTRA", available at:

http://www.minagri.gov.rw/fileadmin/user_upload/documents/Law_and_Regulations/Pla nt_Varieties_in_Rwanda____.pdf (3 February 2018).

36. Pugh, D. S. (1990), Organization Theory: Selected Readings, Harmondsworth, UK: Penguin.

37. Pugh, D. S., Hickson, D. J., Hinings, C. R., Turner C. (1968), "Dimensions of Organizational Structure", Administrative Science Quarterly, Vol. 13, No. 1, pp. 65-105.

38. Rammea, L., Grobbelaar, S. S. (2017), "The Evaluation of e-Government Implementation: A case study of the Lesotho Company Registry System", in Proceedings of 2017 IEEE Africon, Cape Town, South Africa, IEEE, pp. 504-511.

39. RDB (2014), "Document Tracking \& Workflow Management System Report, April 2014", internal document.

40. Republic of Rwanda (2012), "Presidential Order No25/01 of $09 / 07 / 2012$ establishing the list of fees and other charges levied by decentralized entities and determining their thresholds", available at:

http://www.bugesera.gov.rw/fileadmin/user_upload/New_Fees_Presidential_Order_Offici al_Gazette_no_Special_of_27_07_2012.pdf (12 January 2018).

41. Republic of Rwanda (2015), "National ICT strategy and Plan", available at: http://www.gakenke.gov.rw/fileadmin/user upload/NICl III Final Document.pdf (14 January 2017).

42. Republic of Rwanda (2016), "Implementation Framework for the Development and Deployment of Rwanda's Single Integrated e-government Platform", Government of Rwanda, available at:

43. http://www.minagri.gov.rw/fileadmin/user_upload/documents/Job_Vacances/MINAGRI/ IREMBO_IMPLEMENTATION_FRAME_WORK.pdf (12 August 2016).

44. Strejcek, G., Theil, M. (2003), "Technology push, legislation pull? E-government in the European union", Decision Support Systems, Vol. 34, No. 3, pp. 305-313.

45. Suárez-Barraza, M. F. (2013), "Process Innovation in Local Governments: an empirical study of its continuous improvement efforts", Revista Brasileira de Gestão de Negócios, Vol. 15, No. 47, pp. 204-220.

46. The New Times (2018a), "Mutuelle subscribers to use IDs to access healthcare", available at: https://www.newtimes.co.rw/section/read/230824 (12 May 2018). 
47. The New Times (2018b), "Land transfers go online", available at: http://www.newtimes.co.rw/news/land-transfers-go-online (02 May 2018).

48. The New Times (2018c), "New ICT law embodies data privacy protection", available at: https://www.newtimes.co.rw/section/read/207958 (17 May 2018).

49. The New Times (2018d), "Online registration for national exams to save time and money REB", available

at: https://www.newtimes.co.rw/children-education/online-registration-national-exams-savetime-and-money-reb (31 May 2018).

50. Twizeyimana, J D., Larsson, H., Grönlund, $\AA$. (2018), "E-government in Rwanda: Implementation, Challenges and Reflections", Electronic Journal of e-Government, Vol. 16, No. 1, pp. 19-31.

51. UNCTAD (2017), "LDC - What is a least developed country?", available at: http://unctad.org/en/pages/PressRelease.aspx? OriginalVersionID=438 (21 December 2019).

52. United Nations (2014), "United Nations E-government Survey 2014", available at: https://publicadministration.un.org/egovkb/Portals/egovkb/Documents/un/2014Survey/E-Gov_Complete_Survey-2014.pdf (13 February 2018).

53. United Nations (2016), "United Nations E-Government Survey 2016", available at: http://workspace.unpan.org/sites/Internet/Documents/UNPAN97453.pdf (17 September 2017).

54. United Nations (2018), "United Nations E-Government Survey 2018", available at: https://publicadministration.un.org/egovkb/Portals/egovkb/Documents/un/2018Survey/E-Government\%20Survey\%202018_FINAL\%20for\%20web.pdf (1 1 January 2019).

55. Vom Brocke, J., Simons, A., Cleven, A. (2008), "A business process perspective on enterprise content management - towards a framework for organisational change", in Proceedings of the 16th European Conference on Information Systems, Galway, Christchurch, pp. 16801691.

56. von Scheel, H., von Rosing, M., Fonesca, M., Hove, M., Foldager, U. (2014), "Phase 1: Process Concept Evolution", in von Rosing, M., Scheer, A.-W., von Scheel, H. (Eds.), The Complete Business Process Handbook: Body of Knowledge from Process Modeling to BPM, Morgan Kaufmann, pp. 1-9.

57. Weerakkody, V., El-Haddadeh, R., Al-Shafi, S. (2011), "Exploring the complexities of egovernment implementation and diffusion in a developing country: Some lessons from the State of Qatar", Journal of Enterprise Information Management, Vol. 24, No. 2, pp. 172-196.

58. Zmud, R. W., Cox, J. F. (1979), "The implementation process: A change approach", MIS Quarterly, Vol. 3, No. 2, pp. 35-43. 


\section{About the authors}

Pierre Bakunzibake is an Assistant Lecturer at the University of Rwanda, College of Science and Technology. He is also a Ph.D. student in Informatics at Örebro University School of Business, Sweden. Pierre holds a bachelor of engineering in Electronics and Communication Engineering from 2004 and a master's degree in Information and Communication Technologies from 2012. His research interest lies in the areas of information systems and specifically in e-government. Pierre is also a member of the International Network for Postgraduate Students in the area of ICT4D. The author can be contacted at pierre.bakunzibake@oru.se.

Gunnar O. Klein is a professor of informatics at Örebro University. He has been working on a number of different issues for digital government services. During the 1990s, he was a pioneer in introducing national e-identification using cryptographic smart card services in Sweden and in various European Union projects leading to international standards. With a background also in medical science, a focus area has been eHealth solutions where Klein has been working on semantic interoperability also as a leader of European and International Standardization. This engagement has included close contact with government representatives on strategic issues of digitalization in close cooperation with the World Health Organisation and the International Telecommunication Union. Present projects have dealt with decision support systems for the care of elderly with several chronic diseases (the European Union project C3Cloud), a mobile application for acquired immune deficiency syndrome and tuberculosis patients in Mozambique, and citizen empowerment through access to electronic health records. The author can be contacted at gunnar.klein@oru.se.

Sirajul M. Islam is an Associate professor in information systems at the Informatics unit of Örebro University School of Business, Sweden. Dr. Islam is specialized in teaching and research in the areas of e-government, information and communications technology for development (ICT4D), and education with a special interest in marginalized communities in developing regions. He is teaching both at the bachelor and master levels. He has also been involved in journal editorial/review committees and international conferences relevant to ICT4D and e-government. The author can be contacted at sirajul.islam@oru.se. 